\title{
Study of Nutritional Composition of Nopal (Opuntia ficus indica cv. Redonda) at Different Maturity Stages
}

\author{
M.I. Hernández-Urbiola ${ }^{1,2}$, M. Contreras-Padilla ${ }^{3}$, E. Pérez-Torrero ${ }^{2,3}$, G. Hernández-Quevedo ${ }^{4}$, \\ J.I. Rojas-Molina ${ }^{4}$, M.E. Cortes ${ }^{4}$ and M.E. Rodríguez-García*,5
}

\author{
${ }^{1}$ Posgrado en Investigaciones Biomédicas, Universidad Nacional Autónoma de México, Campus Juriquilla, Querétaro, \\ Qro, México, C.P. 76230, A. P. 1-1010, México \\ ${ }^{2}$ División de Ciencias de la Salud, Universidad del Valle de México, Campus Querétaro; Querétaro, Qro, México \\ ${ }^{3}$ División de Investigación y Posgrado, Facultad de Ingeniería, Universidad, Autónoma de Querétaro, Cerro de las \\ Campanas S/N, Querétaro, Qro, México \\ ${ }^{4}$ Facultad de Ciencias Naturales, Licenciatura en Nutrición, Universidad, Autónoma de Querétaro, Cerro de las Cam- \\ panas $S / N$, Querétaro, Qro, México \\ ${ }^{5}$ Departamento de Nanotecnología, Centro de Física Aplicada y Tecnología Avanzada, Universidad Nacional Autónoma \\ de México, Campus Juriquilla, Querétaro, Qro., C.P. 76230, A.P. 1-1010, México
}

\begin{abstract}
Nopal is included in the human diet and used as forage, which is interesting vegetal due to its environmental resistance, but little is known about its nutritional properties along the maturity stage. The objective of this study was to determine the development of the of nopal (Opuntia ficus indica, cv. Redonda) composition at advanced maturity stages in order to evaluate the age related changes in the nutritional composition for suggest its potential use for human consumption. Chemical proximate analysis, mineral constituents and amino acid profile were carried out at different maturation stages. Insoluble dietary fiber, calcium increased from $17.95 \%$ to $34.40 \%$ from $40-135$ days respectively. In addition the ash and phosphorus content also increased. The soluble dietary fiber in nopal decreased as age progressed from 40 to 135 age days. Data also showed that nopal contain 17 amino acids and nine of them are considered essential. The results show that older nopal is an important source of calcium and dietary fiber. Nopal can be an economic alternative for use as food supplement mainly at advanced maturation stage i.e. at 135 days and can be ameliorate or prevent the chronic and degenerative disease.
\end{abstract}

Keywords: Calcium, chemical composition, vegetables, natural products, nutritional aspects.

\section{INTRODUCTION}

The nopal (Opuntia ficus indica) is widely distributed in Mexico and in all American Continent and grow in many other regions of the world, such as Africa, Australia and the Mediterranean [1] Nopal is included in for the Mexican human diet. The cactus pads are commonly called nopales as fresh young nopal from 3-4 weeks of age. Nopales are traditionally consumed in Mexico and in the Unites States, prepared with several different cooking methods. They are usually consumed as salads, but the older stage varieties are also used as cooked consumption items. The advanced mature nopales are sometimes used as forage when fresh food is insufficient due to scarcity of rain. The nopal is cheap, plentiful and the plants have also been used for erosion control [2].

It's important to emphasize the potential nutrimental values related to older maturational stages which currently only

*Address correspondence to this author at the Departamento de Nanotecnología, Centro de Física Aplicada y Tecnología Avanzada, Universidad Nacional Autónoma de México, Campus Juriquilla, Querétaro, Qro., C.P. 76230, A.P. 1-1010, México; Tel: 52-442-2381141; Fax: 52-442-2381165; E-mail: marioga@fata.unam.mx represent use primarily for animal forage. No consideration has been made regarding its it's potential use as nopal powder. This is unfortunate as it contains some essential nutriments that help to maintain human health. The benefits associated with fiber content are well known, especially for ameliorated the symptoms of diabetes, through the reduction of glucose values in the blood, anti-hyperlipidemic and hypercholesterolemic effects [3-6]. A previous study showed that young nopal used for human consume, are rich in calcium (Ca) which increases with nopal age, but has not been investigated extensively [7]. In addition, other studies also demonstrated that nopal possesses a higher content of $\mathrm{Ca}$ than other vegetables included in the diet [8,9]. $\mathrm{Ca}$ is consider an important mineral component for bone metabolism, for that reason, the knowledge of natural sources included in the daily diet, nopal could be an excellent complement of food in order to complement dietary nutritional intake and contribute to for the prevention of some osseous disorders such as osteoporosis. The nopal is an important source of nutritional elements for example pectin, mucilage and minerals. Currently there is only information related to young maturational stage, but little is known about the nutritional value of the older maturational stages. The fresh young cladodes are a source of proteins including essential amino acids, and vita- 
mins. Several studies have reported that high levels of amino acids especially proline, taurine and serine are found in nopal $[1,9,10]$. In contrast not much information is available about amino acids profile at the older nopal ages. Also is noteworthy that there is a gap substantial gap in the studies regarding the nutritional and mineral content at advanced ages of the nopal.

The objective of this work was to evaluate the chemical composition and mineral content of nopal (Opuntia ficusindica, cv. 'Redonda') at different maturity stage from 40 to 135 days, in order to determine the nutrimental contribution for human and animal diets.

\section{MATERIALS AND METHODOLOGY}

Nopal of Opuntia ficus indica cv. 'Redonda' established in the experimental station of the Universidad Nacional Autonoma de Mexico, located at "Los Lores" farm, in Silao, Guanajuato Mexico during the summer period of July to August, 2007. Each sample was made up of $4 \mathrm{~kg}$ of which was collected from several plants in the same sampling areas at different maturity stages from 40 to 135 age days. Samples were then transported to the laboratory and were classified and separated in ten groups according to their age (40, $60,80,100,115,125$ and 135 days respectively).

\section{Dry Vacuum Process}

Nopal was dried using a vacuum system for 12 hours at $10^{-2}$ Torr, and $45^{\circ} \mathrm{C}$, in order to avoid protein and carbohydrate damage. They were then washed with distilled water and disinfected using commercial $10 \%$ sodium hypochlorite solution in order to eliminate microorganisms, the thorns were manually removed and the nopal pads were cut in small sections in order to facilitate the drying process. Finally, the nopal was pulverized to obtain a powder, using a hammer mill (PULVEX 200, Mexico) equipped with a $0.5 \mathrm{~mm}$ screen.

\section{Chemical Proximate Analysis}

Moisture of the nopal flours was determined by desiccation at $40{ }^{\circ} \mathrm{C}$ for $24 \mathrm{~h}$, in accordance with the 934.01 method previously described in publication from the Association of Official Analytical Chemists 2000 (AOAC) [11].

Nitrogen $(\mathrm{N})$ content was obtained by the Kjeldahl method [11], using a $0.5 \mathrm{~g}$ sample. The amount of protein in most materials is calculated by multiplying $\% \mathrm{~N}$ by 6.25 , because most proteins contain $16 \% \mathrm{~N}$. In the present study the protein composition was estimated using a nitrogen factor of 6.25 .

Soluble and insoluble dietary fiber was determined according to the 991.42 and 993.19 AOAC [11] methods. Fat was analyzed by petroleum ether extraction using a Soxhlet apparatus also according to the 920.39 AOAC methods [11].

\section{Ash and Mineral Composition Evaluation Processes}

Ash content was evaluated with the 942.05 AOAC methods [11], using $2 \mathrm{~g}$ sample, determined at $550{ }^{\circ} \mathrm{C}$ for $24 \mathrm{~h}$. Mineral content of nopal was evaluated by atomic absorption spectroscopy (AAS), using an AAS equipment and mass spectrometry ICP-MS in the nopal powders.
For the analysis of $\mathrm{Ca}, \mathrm{Mg}, \mathrm{K}, \mathrm{Na}$ content was using the dry-ashing procedure 968.08 was used [11]. The $\mathrm{Ca}, \mathrm{Mg}, \mathrm{K}$, $\mathrm{Na}$ ions concentration were measured with a double beam atomic absorption spectrometer.

Quantifications of phosphorus (P), manganese (Mn) iron $(\mathrm{Fe})$, zinc $(\mathrm{Zn})$, of nopal powder were carried out by means of mass spectrometry ICP-MS. The tests were performed following the method of AOAC (984.27) (AOAC, 2000) using a Thermo Jarrel Ash, Model IRIS/AP (Corp. Franklin MA USA). Because the equipment scanning all these bulk elements, they were measured but not reported important age related changes.

\section{Extraction and Quantification of Protein}

The protein extraction was achieved according to the Landry [12] methodology. The method described by Hurrell [13] was employed to determine the reactive lysine. The average value of four replicates was reported as $g$ of lysine/100 $\mathrm{g}$ of protein.

Proteins were hydrolyzed and amino acids were analyzed using a HPLC autoanalyzer (Waters 2487, Millipore, MA), following a previous reported method [14]. The tryptophan analysis was made by using the HPLC methodology [15]. The in vitro protein digestibility of dry samples were estimated applying the equation $Y=234.84-22.56 X$ where $Y$ is the in vitro protein digestibility (\%) and $X$ is the $\mathrm{pH}$ of the protein sample suspension, after proteolysis with a multienzyme system [16].

\section{Statistical Analysis}

Data, based on three replicate samples were subjected to analysis of variance. Standard deviation of each individual nutrient of each of the maturity stages mean was computed and variations between maturation stages were evaluated by using ANOVA test and linear regression, in order to evaluate the age related changes. The post hoc analysis was made using a Tukey test at a $(\mathrm{P} \leq 0.05)$. All statistical data were calculated using Statgraphics plus 5.1.

\section{RESULTS}

Fat content showed a tendency of decrease but no significant differences related to age were observed as a function of age $\left(\mathrm{R}^{2}=.3319\right)$. Protein content, no statistically significant differences were observed when compared the values along the studied ages, no direct relationship $\left(\mathrm{R}^{2}=.179\right)$ between protein content and nopal age was observed (Table 1).

The fiber content of nopal increased from $11.00 \mathrm{~g}$ to $23.33 \mathrm{~g}$ from 40 and 135 age-days respectively. The regression test showed direct relationship between the nopal maturity stage and fiber content $\left(\mathrm{R}^{2}=.8462\right)$ (Fig. 1).

The insoluble dietary fiber content increased from 40.14 $\mathrm{g}$ to $56.82 \mathrm{~g}$, from 40 to 135 days but no showed proportional relationship $\left(\mathrm{R}^{2}=0.1381\right)$. The soluble dietary fiber decreased from $25.5 \mathrm{~g}$ (40 days) to $9.8 \mathrm{~g}$ (135 days) and exhibited a direct relationship with the age of the nopal $\left(\mathrm{R}^{2}=0.6523\right)$ (Fig. 1). No statistically significant differences were observed when compared protein content values at all studied ages.

In relation to amino acid content, data demonstrated that nopal contain 17 different amino acids, threonine and iso- 
Table 1. Chemical Composition of Opuntia Dehydrated Nopal on g/100 g of Sample (Opuntia ficus indica Redonda Variety)

\begin{tabular}{|c|c|c|c|c|}
\hline Nopal pads age (days) & $\begin{array}{l}\text { Moisture } \\
\text { (g) }\end{array}$ & $\begin{array}{c}\text { Ash } \\
(\mathrm{g})\end{array}$ & $\begin{array}{l}\text { Fat } \\
(\mathrm{g})\end{array}$ & $\begin{array}{c}\text { Protein } \\
\text { (g) }\end{array}$ \\
\hline 40 & $5.03 \mathrm{~cd}$ & $17.65 \mathrm{a}$ & $2.16 \mathrm{e}$ & $7.07 \mathrm{~b}$ \\
\hline 50 & $8.81 \mathrm{e}$ & $19.59 \mathrm{~b}$ & $2.37 \mathrm{f}$ & $8.99 \mathrm{e}$ \\
\hline 60 & $5.43 \mathrm{~d}$ & $20.64 \mathrm{c}$ & $2.38 \mathrm{f}$ & $8.39 \mathrm{~d}$ \\
\hline 70 & $4.85 \mathrm{bcd}$ & $21.09 \mathrm{~d}$ & $1.62 \mathrm{bc}$ & $8.92 \mathrm{e}$ \\
\hline 80 & $4.36 \mathrm{ab}$ & $21.64 \mathrm{e}$ & $1.53 \mathrm{ab}$ & $7.25 \mathrm{~b}$ \\
\hline 90 & $4.81 \mathrm{bc}$ & $21.92 \mathrm{f}$ & $1.50 \mathrm{ab}$ & $7.78 \mathrm{c}$ \\
\hline 100 & $4.08 \mathrm{a}$ & $22.80 \mathrm{~g}$ & $1.42 \mathrm{a}$ & $8.29 \mathrm{~d}$ \\
\hline 115 & $4.58 \mathrm{abc}$ & $22.91 \mathrm{~h}$ & $1.72 \mathrm{c}$ & $8.48 \mathrm{~d}$ \\
\hline 125 & $4.35 \mathrm{ab}$ & $20.91 \mathrm{i}$ & $1.70 \mathrm{c}$ & $5.85 \mathrm{a}$ \\
\hline 135 & $4.18 \mathrm{a}$ & $24.30 \mathrm{j}$ & $1.87 \mathrm{~d}$ & $7.07 \mathrm{~b}$ \\
\hline
\end{tabular}

Mean values \pm SE followed by the same letter in lines did not showed statistically significant differences $(P \leq 0.05)$ Tukey test.
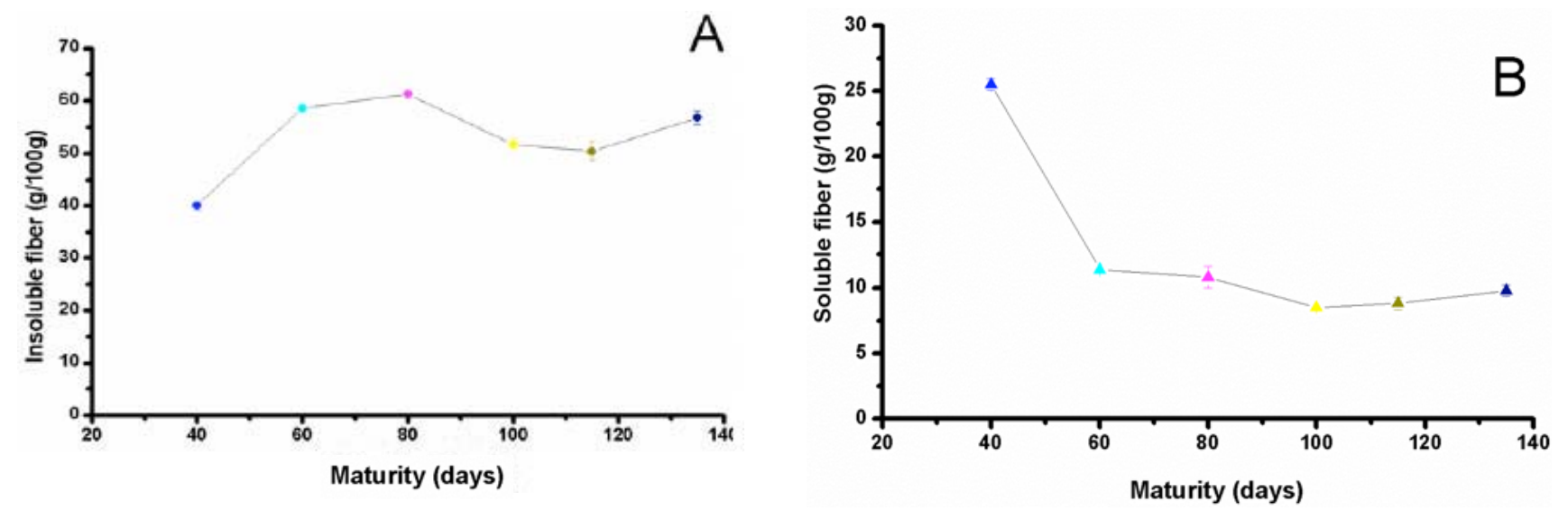

Fig. (1). Concentration of Insoluble fiber (A) and soluble fiber (B) as a functio $n$ of maturity stages. Values are means $+/-$ SD from triplicates samples.

leucine diminished along the studied ages. Valine, metionine and tryptophane content were increased at 60,80 and 50 days, respectively. For the histidine, leucine and lysine, the data revealed an increase related to age. The main component of amino acids corresponds to phenylalanine, threonine and isoleucine for all studied maturity stages (Table 2 ).

The mineral ash composition increased from 17.65 for 40 days to 24.30 for 135 days. The lineal regression analysis showed a positive relationship $\left(\mathrm{R}^{2}=0.7158\right)$ with nopal age. The $\mathrm{Ca}$ and $\mathrm{K}$ (Fig. 2) and Fe composition increased from 40 days to 135 days old. Whereas $\mathrm{P}, \mathrm{Mn}, \mathrm{Zn}$. $\mathrm{Mg}$, and $\mathrm{Na}$ showed statistically significant changes, but without a clear trend according to age (Table $\mathbf{3}$ and Fig. 2).

\section{DISCUSSION AND CONCLUSIONS}

The nopal powders showed a great decrement in the humidity in relation to the fresh nopal inherent to the vacuum drying process; this procedure prevents the proliferation of microorganisms to render the pads edible (Table 1) [17].

The fat content of powders had minimal differences with tendency to decrease in older ages was observed, perhaps due to physiological changes determined by environmental factors such as availability of water (Table 1).

The insoluble dietary fiber content showed a positive relationship related to the age, however, the soluble dietary fiber tended to have a negative relationship, suggesting that older nopal is better source of insoluble fiber (Fig 1). The beneficial health effects of nopal consumption may be due principally to the soluble and insoluble fiber content. In addition, another associated benefit to the fiber composition of the nopal was a decrease observed in the LDL-cholesterol and triglycerides that were observed when the human individual intake supplemented diet with nopal supplemented diet $[4,5,18-22]$.

For protein, no related changes were observed, which was low for all studied ages and similar to those of other vegetables [23] (Table 1). Findings suggest that physical conditions such as water availability, temperature, and lightdark periods are primarily implicated in protein synthesis. Several studies demonstrated that protein synthesis increasing as a cellular protection when the soil is too acid or saline [24-26]. 
Table 2. Amino Acids Contained in Nopal (Opuntia ficus indica) as a Function of Maturity Stages (g/100g of Protein)

\begin{tabular}{|c|c|c|c|c|c|c|c|}
\hline Amino acid & \multicolumn{7}{|c|}{ Age (days) } \\
\hline Glutamic acid & 1.29 & 1.53 & 1.81 & 1.93 & 1.87 & 2.22 & - \\
\hline Serine & 0.32 & 0.47 & 0.42 & 0.46 & 0.56 & 0.65 & - \\
\hline Histidine $^{1}$ & 0.13 & 0.19 & 0.11 & 0.16 & 0.16 & 0.17 & 2.20 \\
\hline Arginine & 0.15 & 0.14 & 0.14 & 0.16 & 0.18 & 0.16 & 7.54 \\
\hline Threonine $^{1}$ & 1.53 & 1.56 & 1.31 & 1.39 & 1.25 & 1.21 & 4.70 \\
\hline Alanine & 0.49 & 0.48 & 0.42 & 0.53 & 0.45 & 0.41 & - \\
\hline Valine $^{1}$ & 0.50 & 0.63 & 0.73 & 0.54 & 0.58 & 0.51 & 6.60 \\
\hline Methionine $^{1}$ & 0.19 & 0.12 & 0.15 & 0.19 & 0.12 & 0.13 & 5.70 \\
\hline Isoleucine $^{1}$ & 0.70 & 0.76 & 0.61 & 0.64 & 0.64 & 0.67 & 5.40 \\
\hline Leucine $^{1}$ & 0.85 & 0.64 & 0.75 & 0.61 & 0.81 & 0.91 & 8.60 \\
\hline Phenylalanine $^{1}$ & 1.69 & 0.93 & 1.39 & 1.36 & 1.21 & 1.61 & 9.30 \\
\hline Lysine $^{1}$ & 0.52 & 0.44 & 0.48 & 0.56 & 0.52 & 0.67 & 7.00 \\
\hline Tryptophan $^{1}$ & 0.15 & 0.19 & 0.17 & 0.14 & 0.15 & 0.17 & 4.70 \\
\hline
\end{tabular}

${ }^{1}$ Esential amino acid.

${ }^{2}$ Egg corresponding values [28].
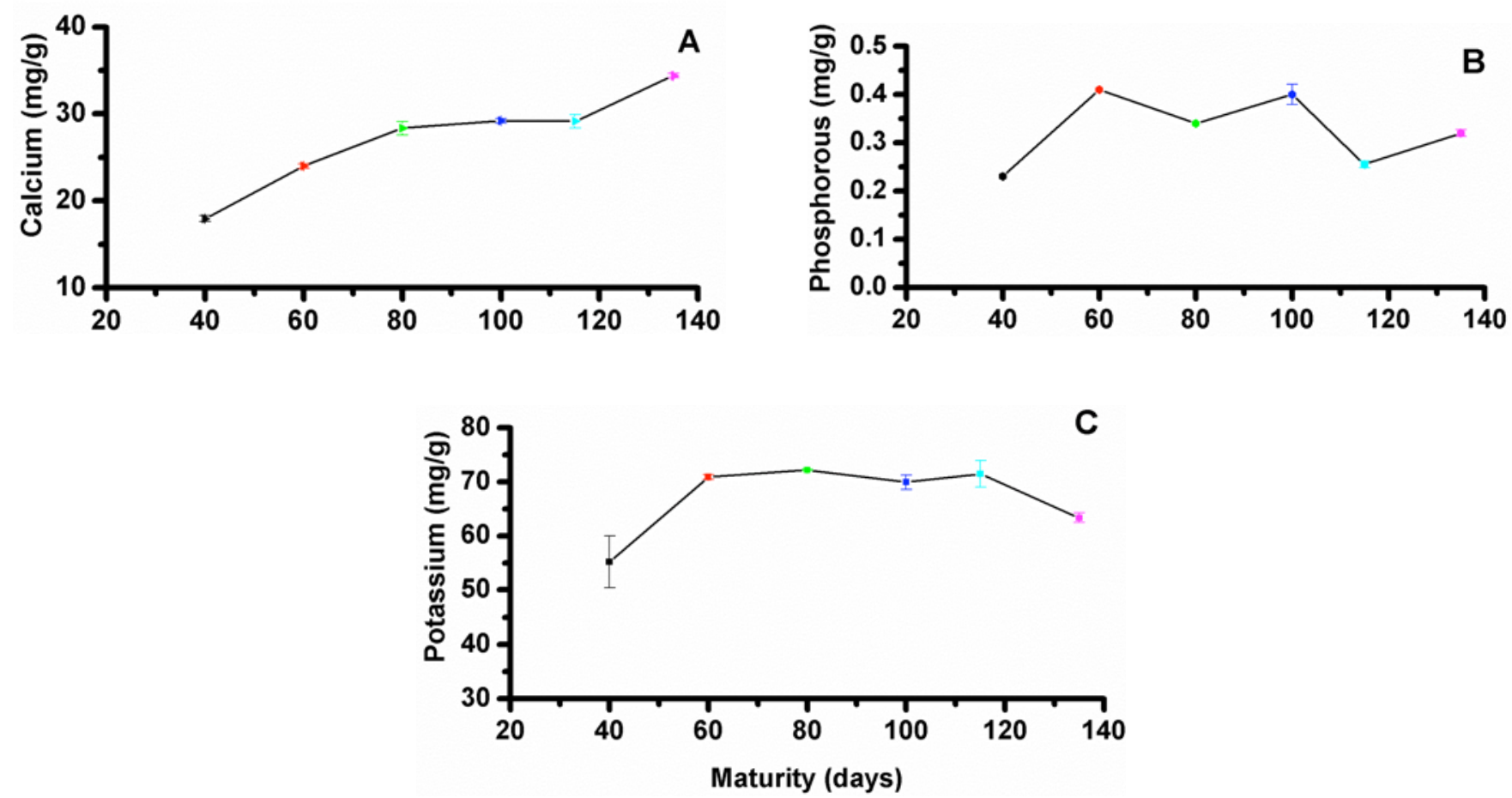

Fig. (2). Calcium concentration (A), phosphorous concentration (B) and potassium concentration (C) of nopal pads at different maturation stages (days). Values are means +/- SD from triplicates samples. 
Table 3. Mineral Composition, of Nopal Powder at Different Maturational Stage (Age-Days)

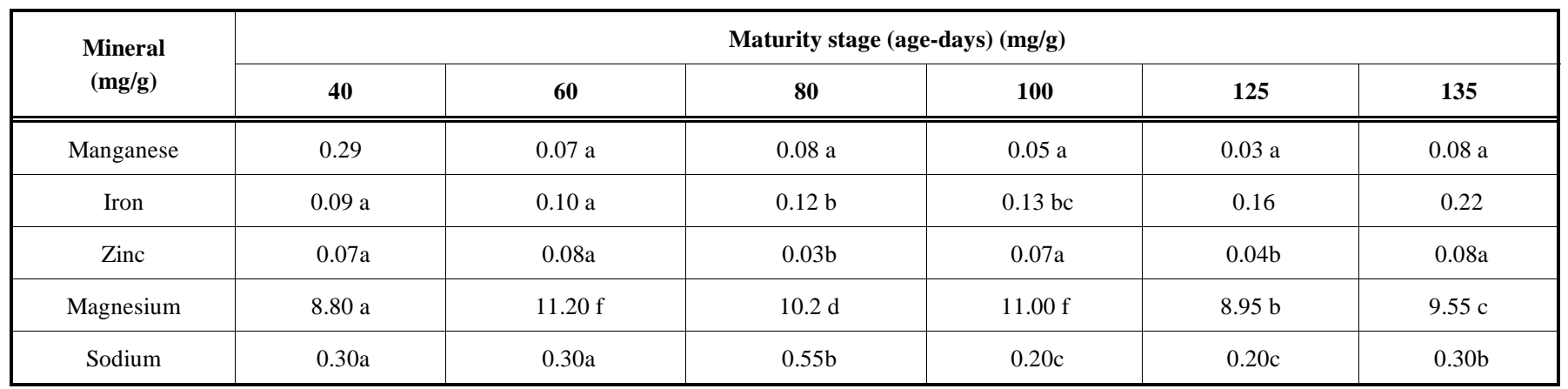

Mean values \pm SD followed by the same letter in lines none showed statistically significant differences $(P \leq 0.05)$ Tukey test.

In relation to the amino acid content, analyses showed that nopal contain $\mathbf{1 7}$ different amino acids, nine of which are considered essential, and showed different levels of content related to the maturity stages. For instance threonine and isoleucine diminished in relation to age, suggesting that younger samples are better source for these amino acids. For the histidine, leucine and lysine content, the data revealed an increase associated with older ages. Finally the major content of amino acids corresponds to phenylalanine, threonine and isoleucine for all age groups. These findings suggest that the nopal powders might be a good complement to other vegetables, meat and dairy products included in daily diets due to their essential amino acids content, see Table 2.

The ash content of minerals $\mathrm{Ca}$ and $\mathrm{Fe}$ were increased from 40 to 135 days old samples, whereas P, Mn and Zn not showed age related changes. Further suggesting that some elements of ash chemical composition depend on different factors, such as pH, water availability, soil texture and composition where the nopal grow. Previous studies reported that the main elements in ash are $\mathrm{Ca}$ and potassium, followed by magnesium, sodium, and small quantities of iron and manganese (Table $\mathbf{3}$ and Fig. 2). These elements are present in carbonates, chlorides, sulfates and phosphates [27].

The benefits of including nopal in human diets are primarily related to the $\mathrm{Ca}$ content which is present and contributes to maintaining healthy strong bones. Although many vegetables are important sources of $\mathrm{Ca}$, for example soy, spinach, grains and chard, nopal appear to be a better source of the mineral $\mathrm{Ca}$ due to their elevated content [5,23]. Phosphorous content in the diet is thought to be the second most important mineral in the formation of bone. Even though phosphorous levels are low in nopal powders, in general some grains like legumes contribute a substantial amount of this mineral [7].

Data suggest that the best age to harvest and consume are 135 days old, for their elevated calcium content. Furthermore, results also indicate that the nopal is rich sources of nutriment and can be used for medicines and cosmetics. Nopal have potential applications in the prevention and treatment of diseases such as osteoporosis, due its $\mathrm{Ca}$ content and for diabetes treatment due to the fiber content, because the evidence of medicinal properties for the nopal and also for the cosmetic consistency based in the fiber composition. Because this study showed that nopal is a significant source of fiber $[19,20]$. Related to the fact that nutritional deficiencies are currently widespread in many poor areas of the world most especially among the children in the developing countries, attention, therefore, must be focused on the inexpensive solutions, such as nopal powders, in order to take advantage of its production period. Nopal powders can be an economic alternative when used as supplement throughout all seasons without the production of fresh nopal. The dried products represent certain advantages for transport and preserving these products for prolonged periods in optimal conditions to ensure the nutritional quality and availability.

Nopal can be a rich source of soluble fiber during younger ages, and increased the insoluble fiber content at older ages. A noteworthy observation from this study is the proposal of increasing intake of older nopal powder in daily diets, related to the increased $\mathrm{Ca}$ content at advanced nopal age.

However, the authors believe that additional research is needed to understand more about the potential multiple applications in the processed foods for human consumption and pharmaceutical uses regarding the additional nutritional.

\section{ACKNOWLEDGEMENTS}

This research was partially supported by the Consejo Nacional de Ciencia y Tecnologia (CONACyT), México Grants 14069 and 91211. The authors want to thank MS Aracelí Aguilera Barreiro (Animal Nutrition Laboratory FCN-UAQ), I. Q. Carmen Vázquez Ramos (Physicochemical Food Laboratory CFATA/UNAM) and Carolina Muñoz Torres (Geosciences UNAM) for technical support. Finally, we like to thank Silvia Stroet of the University's Edition Office (FI-UAQ) for editorial and language assistance and Dr. Ramón Álvar Martínez Peniche for revision and invaluable comments.

\section{REFERENCES}

[1] Piga A. Cactus pear, a fruit of nutraceutical and functional importance. J Profess Assoc Cactus Dev 2004; 6: 9-22.

[2] Le Houérou HN. The role of cacti (Opuntia spp.) in erosion control, land reclamation, rehabilitation and agricultural development in the Mediterranean Basin. J Arid Environ 1996; 33: 135-59.

[3] Reid IR, Ames RW, Evans, MC, Gamble GD, Sharpe SJ. Longterm effects of calcium supplementation on bone loss and fractures in postmenopausal women a randomized controlled trial. Am J Med 1995; 98: 331-35.

[4] Palumbo B, Efthimiou Y, Stamatopoulos J, et al. Prickly pear induces upregulation of liver LDL binding in familial heterozygous hypercholesterolemia. Nucl Med Rev 2003; 6: 35-9.

[5] Feugang JM, Konarski P, Zou D, Stintzing FC, Zou C. Nutritional and medicinal use of cactus pear (Opuntia spp) cladodes and fruits. Front Biosci 2006; 11: 2574-89. 
[6] Gebremariam T, Melaku S, Yami A. Effect of different levels of cactus (Opuntia ficus-indica) inclusion on feed intake, digestibility and body weight gain in tef (Eragrostis tef) straw-based feeding of sheep. Anim Feed Sci Technol 2006; 131: 42-51.

[7] Rodríguez-García ME, De Lira C, Hernández-Becerra E, et al. Physicochemical characterization of prickly pads (Opuntia ficus indica) and dry vacuum prickly pads powders as a function of the maturation. Plant Food Hum Nutr 2007; 62: 107-12.

[8] McConn MM, Nakata PA. Oxalate reduced calcium availability in the pads of the prickly pears cactus through formation of calcium oxalate crystals. J Agric Food Chem 2004; 52: 1371-74.

[9] Stintzing FC, Carle R. Cactus stems (Opuntia spp.): A review on their chemistry, technology, and uses. Mol Nutr Food Res 2005; 49: 175-194.

[10] Stintzing FC, Schieber A, Carle R. Phytochemical and nutritional significance of cactus pear. Eur Food Res Technol 2001; 212: 396407.

[11] Horwitz W. Ed. AOAC, official methods of analysis of the Association of Official Analytical Chemists. $17^{\text {th }}$ ed. Gaithersburg: Maryland, USA 2000.

[12] Landry J, Delhaye S, Damerval C. Improved method for isolating and quantitating $\alpha$-amino nitrogen as nonprotein, true protein, saltsoluble proteins, zeins and true glutelins in maize endosperm. Cereal Chem 2000; 77: 620-26.

[13] Hurrell RF, Lerman P, Carpenter KJ. Reactive lysine in foodstuffs as measured by a rapid dye-binding procedure. J Food Sci 1979; 44: 1221-27.

[14] Bidlingmeyer BA, Tarvin TL. Rapid analysis of amino acids using pre-column derivatization. J Chromatogr 1984; 336: 93-104.

[15] Yomashita Y, Tonoue E. Distribution and alteration of amino acid in bulk DOM along a transect from bay to oceanic waters. Mar Chem 2003; 82:145-160.

[16] Hsu HW, Vavak DL, Satterlee LD, Miller GA. A multienzyme technique for estimating protein digestibility. J Food Sci 1977; 42: 1269-73.
[17] Geankoplis CJ. Procesos de transporte y operaciones unitarias. $4^{\text {th }}$ ed. México: Continental 2006.

[18] Frati-Munari AC, Del Valle-Martínez LM, Ariza-Andraca CR, Islas-Andrade S, Chávez-Negrete A. Hypoglycemic action of different doses of nopal (Opuntia streptacantha Lemaire) in patients with type II diabetes mellitus. Archiv Invest Méd (Mex) 1989; 20: 197- 201

[19] Frati MAC, Xilotl DN, Altamirano P, Ariza R, López LR. The effect of two sequential doses of estreptacantha upon glycemia. Archiv Invest Méd (Mex) 1991; 22: 333-6.

[20] Periago MJ, Ros G, López G, Martínez MC, Rincón F. The dietary fiber components and their physiological effects. Rev Esp Cienc Tecnol Aliment 1993; 33: 229-46.

[21] Sáenz C. Cladodes: a source of dietary fiber. J Profess Assoc Cactus Dev 1997; 2: 117-123.

[22] Torres-Tamayo M, Trejo-González A, Posadas-Sánche R, et al. Efecto del extracto de nopal sobre lípidos y lipoproteínas en hipercolesterolemia moderada. Rev Med IMSS 2001; 39: 491-99.

[23] Lee Y-C, Pyo Y-H, Ahn C-K, Kim S-H. Food functionality of Opuntia ficus-indica var. Cultivated in Jeju Island. J Food Sci Nutr 2005; 10: 103-10.

[24] Nobel PS, Israel AA. Cladode development, environmental responses of $\mathrm{CO}_{2}$ uptake, and productivity for Opuntia ficus-indica under elevated $\mathrm{CO}_{2}$. J Exp Bot 1994; 45: 295-303.

[25] Drennan PM, Nobel PS. Responses of CAM species to increasing atmospheric $\mathrm{CO}_{2}$ concentrations. Plant Cell Environ 2000; 23: 76781.

[26] Aguilar BG, Peña VCB. Alteraciones fisiológicas provocadas por sequía en nopal (Opuntia ficus-indica). Rev Fitotec Mex 2006; 29 ; 231-27.

[27] Granados SD, Castañeda PAD. El nopal historia, fisiología, genética e importancia. México: Trillas 1997.

[28] FAO/WHO/UNU. Energy and protein requirements. Report of a joint $\mathrm{FAO} / \mathrm{WHO} / \mathrm{UNU}$ expert consultation. Technical report series no. 724. Geneva: World Health Organization 1985.

(C) Hernández-Urbiola et al.; Licensee Bentham Open

This is an open access article licensed under the terms of the Creative Commons Attribution Non-Commercial License (http://creativecommons.org/licenses/by-nc/3.0/) which permits unrestricted, non-commercial use, distribution and reproduction in any medium, provided the work is properly cited. 